James A. Kelhoffer

\title{
Conceptions of »Gospel« and Legitimacy in Early Christianity
}

[Vorstellungen von »Evangelium« und Legitimität im frühen Christentum.]

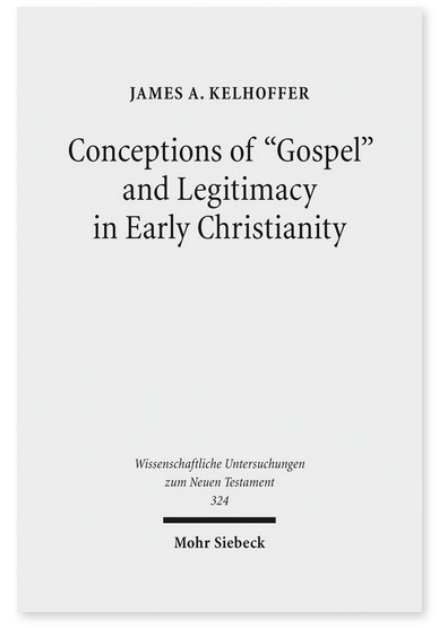

2014. XXIII, 400 Seiten. WUNT I 324

ISBN 978-3-16-152993-1

DOI 10.1628/978-3-16-152993-1

eBook PDF $179,00 €$

ISBN 978-3-16-152636-7

Leinen $179,00 €$
Veröffentlicht auf Englisch.

Ganz gleich, ob er die Rolle der Exegese des Neuen Testaments in anderen wissenschaftlichen Disziplinen untersucht, die

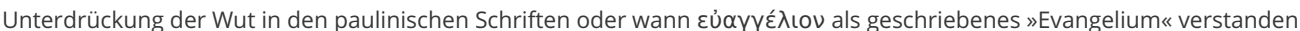
wurde, die geduldige und vorsichtige Exegese James A. Kelhoffers bietet spannende Einblicke in das frühe Christentum. Er zeigt, dass viele Anstrengungen der frühchristlichen Gläubigen den innerkirchlichen Kampf widerspiegeln, der die Legitimität eines Standpunktes oder eines religiösen Führers gegenüber konkurrierenden Ideologien oder Anführern begründet. Die Leser, denen Kelhoffers bereits erschienene Bände Miracle and Mission (2000), The Diet of John the Baptist (2005) and Persecution, Persuasion and Power (2010) bekannt sind, werden in diesem Band neue Einblicke erlangen, auf die in seinen bisherigen Werken hingewiesen, die aber noch nicht ausgearbeitet wurden.

\section{Inhaltsübersicht}

I. Reflections on Method

New Testament Exegesis as an Academic Discipline with Relevance for Other Disciplines - Early Christian Studies among the Academic Disciplines - The Significance of the Earthly Jesus in Matthew

II. Conceptions of »Gospel« in Early Christianity

»How Soon a Book« Revisited: EUAГTENION as a Reference to »Gospel« Materials in the First Half of the Second Century Basilides's Gospel and Exegetica (Treatises ) - The Struggle to Define Heilsgeschichte: Paul on the Origins of the Christian Tradition - The Witness of Eusebius's ad Marinum and Other Christian Writings to the Original Conclusion of Mark

\section{Struggles for Legitimacy}

The Maccabees at Prayer: Pro- and Anti-Hasmonean Tendencies in the Prayers of First and Second Maccabees - Suffering as Defense of Paul's Apostolic Authority - Paul and Justin Martyr on the Miraculous: A Comparison of Appeals to Authority - The Gradual Disclosure of Paul's Violence against Christians in Acts as a Defense of the Lukan Paul - Revelation's Date, the Imperial Cult and the Value of Christians' Suffering in Revelation 1-3 - »Hippolytus « and Magic: An Examination of Elenchos IV.28-42 in Light of the Greek Magical Papyri - The Search for Confessors at the Council of Nicaea

IV. Varia

Suppressing Anger in Early Christianity: Examples from the Pauline Tradition - Early Christian Ascetic Practices and Biblical Interpretation: The Witnesses of Galen and Tatian

James A. Kelhoffer Born 1970; 1999 PhD University of Chicago; 2003 postdoctoral fellow Catholic Biblical Association of America; 2007 postdoctoral fellow Alexander von Humboldt Foundation at Ludwig-Maximilians-Universität München; currently Professor of New Testament Studies at Uppsala University (Sweden).

Jetzt bestellen:

https://mohrsiebeck.com/buch/conceptions-of-gospel-and-legitimacy-in-early-christianity-9783161529931?no_cache=1 order@mohrsiebeck.com Telefon: +49 (0)7071-923-17

Telefax: $+49(0) 7071-51104$ 